\title{
Alain Chartier: The Manuscript and Print Tradition ${ }^{1}$
}

There has been a recent surge of critical interest in the manuscripts - their construction, design, and content - in which Alain Chartier's works were transmitted in the course of the 15th and early 16th centuries. ${ }^{2}$ Such interest has intersected with a more general scholarly move to integrate analysis of the codex - the material support upon and within which a medieval text is inscribed or printed, decorated, bound, and read - with readings of the texts it contains. ${ }^{3}$ In Chartier's case, many of the most fruitful discussions of manuscript context have arisen from analyses of manuscript recueils or anthologies which collect his works with a vast array of different texts, some of which were conceived of as direct responses, rebuttals or other kinds of engagement with particular Chartier works. ${ }^{4}$ Ardis Butterfield observes of medieval manuscript recueils that, "we seek to follow the medieval act of compilation so closely that it will reveal to us the original hermeneutic force that impelled the juxtaposition of text with text ... the object of study is not so much the recueil itself but the acts of interpretation that it represents.”5

Precisely this critical focus has been applied within recent approaches to extant Chartier manuscripts, particularly those developed by Cayley, McRae, Armstrong and Hult. These critics have sought not just to shine a spotlight on certain Chartier texts or manuscripts, but to trace productive connections, oppositions and tensions between works gathered within Chartier codices as a whole: "many of the manuscripts which transmit Chartier’s œuvre hint at collaboration and debate beyond and through the confines of the material page”. ${ }^{6}$ Within this chapter, I extend these critical approaches outward to consider the earliest appearance of Chartier's works in print, a topic which has yet to receive the scholarly attention that has been accorded to extant Chartier manuscripts. Chartier’s works survive in a plethora of printed formats; for the purposes of this chapter, I focus briefly on the proliferation of large, Parisian 
printed volumes of “collected works”, whose title-pages and arrangement pivot around Chartier's name, before considering in detail a selection of individually-printed Chartier texts, issued in a variety of locations. ${ }^{7}$

Les Fais: Chartier and his “Collected Works”

The earliest extant edition of a "collected works" of Chartier, printed in folio, was issued in Paris by Pierre Le Caron in 1489, and entitled Les Fais maistre alain chartier notaire et secretaire du roi Charles vii. It was swiftly followed, in 1494, by a reprint, for which Le Caron appears to have collaborated with Antoine Vérard, well-known and successful libraire. ${ }^{8}$ In this second edition, titled Les Faiz maistre alain charetier, Vérard's printer's mark appears at the close of the text, but with Le Caron’s name substituted for Vérard's initials. The 1494 Faiz was also, however, issued by Vérard alone, with his own initials replaced in his printer's mark by the illuminator, as a deluxe manuscrit-imprimé $e^{9}$ to present to Charles VIII. Extant in the Bibliothèque nationale de France $(\mathrm{BnF})$, this large volume is printed on high-quality vellum, with individual illuminations and borders for virtually each text. ${ }^{10} \mathrm{~A}$ third version, Les Fais maistre alain charetier, c. 1498, also exists, with Vérard's name in the colophon alongside Le Caron's, and Vérard's initials reinstated within his printer's mark. ${ }^{11}$ These three Fais formed the bedrock of a tradition of printed Fais Alain Chartier volumes in Paris, extending forward for 40 years to Galliot du Pré's 1526 and 1529 volumes, ${ }^{12}$ and ultimately to du Chesne’s Euvres de Maistre Alain Chartier in $1617 .{ }^{13}$

As Laidlaw notes, the content and organisation of printed Fais volumes remains, broadly speaking, the same, as they are issued by printer after printer in the years $1489-1526 .{ }^{14}$ Chartier's Latin works are always excluded from these volumes (except De vita curiali, present in its vernacular translation) ${ }^{15}$; some were issued separately in different contexts. The Fais volumes 
are divided into prose and verse sections, although the opening prose section is begun by the Livre de l'Esperance, a prosimetric text. Each section contains what appear to be "fillers" of non-Chartier pieces, in prose and verse respectively, including works by Taillevent, Oton de Grandson and Guillaume de Machaut, as well as several non-Chartier Querelle de la Belle Dame sans mercy texts including the Hôpital d'amours and the Belle Dame qui eut mercy. ${ }^{16}$ The Debat des deux fortunés d'amour is never printed in these Fais volumes, despite its mention of Chartier’s name at l. 1245, until du Pré 1526, whose title-page proclaims the pains he has taken to "correct" the authorial corpus preserved in earlier editions, and to reinstate the "débat du gras et du maigre”. The Debat had, however, previously been printed within Vérard's 1501 anthology Le Jardin de Plaisance, where it occurs in a loosely-Chartier-related subsection including several texts associated with the Querelle de la Belle Dame sans mercy and a series of Chartier's rondeaux reworked into a dit. ${ }^{17}$

The 1489 and 1494 collected Chartiers both make use of a large, fashionable, calligraphic "L" to form the centerpiece of their title-pages (see Fig. 1); as Hillard has shown, Le Caron used this "L" for the first time in his 1489 Fais, having copied it from the original "L" introduced by Jean du Pré de Paris and Pierre le Rouge. ${ }^{18}$ Le Caron employs this distinctive, still-new title-page design to assert Alain Chartier’s “ownership” over the texts contained within the Fais volumes although, as many have noted, these texts are certainly not all by Chartier. ${ }^{19}$ Chartier's works are rarely attributed to him in manuscripts, and no manuscript claims to contain all of his works, even those which do, in fact, preserve a great deal. ${ }^{20}$ To advertise a corpus of texts in print centered around Chartier's name and academic rank, then, was to innovate. ${ }^{21}$ Although the calligraphic "L" falls out of fashion as a decorative feature of Fais title-pages post-1498, to be replaced by a variety of woodcuts and borders, ${ }^{22}$ a second feature remains constant from 1494- 
1526. This is a quatrain punning on Chartier's name and use of the term faiz to describe his works:

Tous charetiers tant par faiz qu'imparfaiz

Qui charier veulent droit sans mesprendre

De maistre allain charretier les beaux faiz

En ce livre mis au vray doivent prendre.

[All cart-drivers, both perfect and imperfect, who want to drive their carts straight, without error, the beautiful faiz of maistre Alain Chartier should take from this corrected book.]

In addition to punning on Chartier’s name to create an analogy between cart-driving and "right living” (if this is what "straight driving” intends to convey), the poem also puns on the idea of faiz; the word parfaiz has been split, isolating the term faiz, which is then repeated, this time meaning the content of the book. The first miniature inserted into Vélins 582 illustrates this punning quatrain. It shows Alain Chartier being pulled past Charles VIII in a horse-drawn cart. Chartier is reading out loud from a book as he sails past, the King has his finger raised to indicate verbal response. The miniature spells out visually the connection between Chartier, the cart and the faiz; the central figure of Chartier as an advisory authority "pulling together” the Faiz is foregrounded. ${ }^{23}$

Vérard’s interest in asserting his ownership over Vélins 582, through the reinstatement of his own initials and the effacement of Le Caron's in the monogram at its close, most obviously relates to his conceptualization of this particular book as a bespoke presentation volume prepared personally by him for the king. However, colophons and printers' monograms may also be seen more generally as ways of asserting an identity for the book as part of a particular printer's output. "Maistre Alain Chartier”'s presence on the title page mirrors the presence of the printer 
in a monogram or colophon at the close of the text; both are conjointly responsible for the content and "identity" of the book.

David Hult has recently characterized the 1489 (and subsequent) Fais as a “dramatic” break with manuscript tradition: "the first printed edition marks a dramatic turn away from the manuscript transmission of Chartier's works by virtue of the authorial attribution imposed by the title page."24 This formulation is obviously true to an extent. However - as Hult notes - the situation is clearly more complex than initially appears. Firstly, very many manuscripts frequently anthologize Chartier with non-Chartier works, exactly as do the early collected editions. Those Chartier manuscripts that do appear to center themselves around an authorial corpus very often contain some form of the Querelle de la Belle Dame sans mercy, and so assert dialogic, intertextual, outward-reaching aspects of Chartier's work as characteristic of his authorial "presence". ${ }^{25}$ In this way, Le Caron and those who follow him, despite their innovatory title pages, in fact follow in the footsteps of a manuscript tradition. What is new, or different, is the active deployment of Chartier's name as a collective banner under which non-Chartier texts may also be gathered, a move which has recently been recognized, in the context of other authors, as characteristic of a developing “print culture”. ${ }^{26}$

Secondly, methods of textual circulation in manuscript and in printed formats cannot be regarded as entirely discrete. ${ }^{27}$ Many manuscripts whose contents and construction have given rise to important recent scholarship on Chartier were copied roughly contemporaneously with the rise of print as an alternative method of book production. Intermingling between the two modes of textual production occurred in several areas; one pertinent manuscript example is BnF, fr. 833, a Chartier manuscript copied from Le Caron's Faiz, complete with a hand-drawn title-page containing the grotesque capital “L” and “charretier” verses. Vérard’s manuscrits-imprimés of 
the Faiz, including Vélins 582, are also a testament to overlap between the two media. Conversely, early printed copies of single Chartier works, which are sometimes printed anonymously, may be fruitfully contextualized with manuscript evidence. While an important part of the printed Chartier tradition, collected editions only give a partial picture of Alain Chartier in print. Single-work volumes - their marketing, appearance and histories - form a significant and overlooked counterweight to the "collected Chartiers" discussed above. Alternative Narratives: Early Editions of Individual Chartier Works

Paul Needham has argued of 15th and 16th-century Sammelbände - bound volumes collecting together two or more individually-printed works - that "the volume, not the edition ... constitutes the unit of ownership". ${ }^{28}$ The selection, ordering and presentation of the printed texts found in Sammelbände constitutes an interpretative response to these texts by their earliest readers. Gillespie notes a key analogue for printed Sammelbände in England: "late medieval vernacular manuscript booklets, and volumes compiled or derived from these.”" ${ }^{29}$ This approach to reading early printed books clearly intersects fruitfully with recent critical moves to foreground the manuscript context(s) of Chartier's æeuvre, especially those developed by McRae in relation to the Querelle de la Belle Dame sans mercy. ${ }^{30}$

Despite a poor survival rate, Needham suggests that "many fifteenth century books ... were once in Sammelbände”. ${ }^{31}$ Verse texts such as Chartier's Complainte contre la mort or Lai de paix are likely candidates for inclusion in a Sammelbände of short pieces, rather than individual binding. The copy of the Lai de paix issued c. 1490s in Lyon by the Imprimeur du Champion des Dames (hereafter ICD) is only six folios long, so too is his Complainte. The same printer's Belle Dame sans mercy runs to 20 folios, still a short text to bind alone when compared to the edition that gave him his sobriquet, Martin Le Franc's Champion des dames (186 folios). 
Binding a text entailed cost; from a practical view it may have seemed more sensible to collect shorter texts together to be bound in one volume, rather than paying for individual bindings. The evidence of Jena, ULB Op. Th. IV q. 17 Inc. and A. r. XII. q. 1 Inc., two early French vernacular Sammelbände still in 15th-century bindings, demonstrates that this method was indeed employed to house short, printed vernacular texts. ${ }^{32}$ Shaw describes the 13 items comprising Op. Th. IV q. 17 Inc. as "pamphlet items"; they range from six to 52 folios in length, including six six-folio texts, and one each at 12,14 and 16 folios. ${ }^{33}$

Such considerations are important for a discussion of individual Alain Chartier editions because many such editions, and the texts with which they are frequently issued, are comparatively short. ${ }^{34}$ In some cases printers possibly marketed a series of such texts to be read alongside one another; this strategy might suggest to readers that they collect these texts together in much the same way as they might have noted intertextual connections when creating or commissioning manuscript recueils. In the following section, then, I discuss the individual Alain Chartier editions issued by three of his earliest printers: Colard Mansion (Bruges), the ICD (Lyon), and the Foucquet-Crès atelier (Brittany). I consider other works marketed by these printers, their marketing strategies, and, where possible, the codicological histories of extant copies of their Chartier texts. I suggest, in sum, that Chartier's strong presence in 15th-century manuscript recueils may have exerted an influence on the ways in which incunable copies of his individual works were packaged and read. This packaging forms a counter-point to the Parisian “collected Chartier” editions discussed above, and creates a different narrative of textual transmission to what might be thought of as a dominant, largely self-perpetuating tradition of “collected Chartier in print”. Such dominance is, for example, obliquely encoded in the label “first printed edition" which Hult applies to the 1489 Fais. ${ }^{35}$ While this is certainly the first 
extant collected edition, it is not the first Chartier text to be printed; the Quadrilogue invectif (QI), for example, was issued twice during the 1470 s.

The Quadrilogue in Bruges

Colard Mansion was active as a printer and scribe in Brugge (Bruges) c. 1476-1484, when he issued texts predominantly in French aimed at a wide range of consumers. ${ }^{36}$ He was for a time in collaboration with William Caxton, before Caxton left Bruges for Westminster c. 1476. ${ }^{37}$ One of the French-language texts that Mansion brought out early in his decade of printing was Chartier’s QI, very probably issued in 1477: “A la matiere de cestui liure se peut equiparer celle du / temps present de lan lxxvii” [The qualities/events of the present time, the year '77, may be compared with the subject matter of this book]. ${ }^{38}$ The cusp of 1476/7 was, of course, the year in which Charles the Bold, Duke of Burgundy was prematurely killed in battle, and succeeded by his daughter Marie. This situation led to widespread insecurity and friction between trade guilds and ducal administrators in many areas of the duchy, including Bruges. ${ }^{39}$ It also left the Burgundian territories weakened, rendering them a target for French acquisition. Mansion explicitly repackages the QI to suit 1477 Bruges, suggesting that it may be appropriate and useful reading for these turbulent times, and that it might recall to their proper duties all three estates of Brugeois society.

Catherine Nall has recently discussed the ways in which the QI, twice translated into English in the 15th century, was read by English readers in the context of the Wars of the Roses. Nall's work suggests that the relevance of the QI was not confined to the immediate context from which it arose, the Hundred Years' War from the perspective of a jaded French side. ${ }^{40}$ Mansion's re-packaging of the text, through his added printer's prologue, to address the unstable political situation in 1477 Bruges, points to another instance of such widely-understood utility, and 
suggests that Chartier was valued broadly for the social and political critiques he articulated. Mansion printed a second text addressing the Brugeois political situation in 1477, appending a prologue and epilogue which refer to recent political events in similar terms to the QI's prologue: a French translation of Boethius's De consolatione. ${ }^{41}$ Cayley has demonstrated how, in certain manuscripts, Chartier is carefully associated with, and authorized by, earlier auctores. ${ }^{42}$ Chartier himself formally imitated the prosimetric structure of Boethius in his Livre de l'Esperance, his only prosimetric work, ${ }^{43}$ and 25 manuscripts of the QI unite it with the Esperance. ${ }^{44}$ Here, I suggest, Mansion follows in the footsteps of these manuscript traditions, and associates Chartier with Boethius as a pair of equally well-equipped advisor-figures by issuing their texts close together in 1477, with corresponding paratextual material.

Many of the other short French texts produced by Mansion intersect fruitfully with the themes of the QI, particularly the Abuzé en court and a pair of two short debate texts, the Controversie de noblesse and the Débat entre trois chevalereux princes. The Controversie and the Débat, although now catalogued as two separate texts, in fact were marketed as one printed unit. Mansion’s Débat opens with an explicit reference back to the Controversie, which it describes explicitly as “[le] premier traittie” [the first treatise] in a set of two. Each debate-text of this pair discusses the true nature of nobility and honor. As Schoysman notes, both texts "sont des traductions d'humanistes italiens ... qui mettent en scène des personnages de l'antiquité”; 45 the Débat pits Alexander the Great, Hannibal and Scipio the African against one another in front of their judge Minos, each claiming to be the most honorable. The Controversie consists of two speeches given by Publius Cornelius Scipion (noble by birth) and Gaius Flaminius (noble in deeds), two rival suitors. 
Both texts were translated from Latin in the mid-15th century by Jean Miélot, secretary and translator at the court of Phillip, Duke of Burgundy, who commissioned the translations, and was the recipient of a lavish presentation manuscript of both. ${ }^{46}$ Mansion's decision to link the texts goes back to this manuscript history; in the vast majority of manuscripts, they are presented consecutively as a pair. They form an example of the interest in early humanist literature, culture and erudition, and in book production and art associated with the ducal courts of Burgundy, particularly that of Phillip the Good. ${ }^{47}$ Mansion thus offers his readers a literary product with very prestigious associations. His choosing to print Chartier’s QI alongside these texts associates it with those commissioned by Phillip. It also, of course, associates Phillip’s interest in translating Latin humanist texts with the concerns voiced in the QI; all three texts interrogate the concepts of true nobility, good governance, and the importance of an individual's actions living up to their role in society.

In terms of their form and their content, then, both texts may fruitfully be compared to Chartier's QI, and more generally to his literary output and ethical stance. Cayley and Armstrong have both demonstrated conclusively the importance of the debate structure to Chartier's work, particularly his frustration of a neat sense of closure within his debates, leading to further engagements with the problem discussed. ${ }^{48}$ The inconclusivity, indeed futility, of the QI's debate as to who is to blame for France's plight, and the patent lack of agreement and goodwill between the protagonists, is figured by France paradoxically as a generative, "fructueuse” force for good: “J'ayassez ouy de vos tençons ... [et] j’ordonne vos raisons estre escriptes ... que cy endroit n’aiez pas disputacion haineuse mais fructueuse” [I've heard enough of your disputes, and I order that your words be put into writing, so that your present argument may be fruitful, rather than full of hate]. ${ }^{49}$ It is only Chartier's production of a written record, however, which enables 
this social "fruitfulness" to be accessed by readers. The act of disseminating the written $Q I$ is what allows its "disputacion haineuse” [argument full of hate] to be transformed by careful reading into a didactic, profitable text, one which provokes (re)action. ${ }^{50}$ Miélot’s debates superficially conclude; however, both conclusions, particularly that of the Débat, are somewhat perfunctory, and therefore also demand their reader's intellectual participation, prompting them to consider for themselves the nature of true nobility. One further area of potential overlap between the three texts can be found in their verbal format. Schoysman considers the paratextual features and illuminations of Phillip the Good's Controversie/Débat manuscript suggestive of verbal performance, even theater. ${ }^{51}$ Although France highlights the written nature of the QI, Chartier’s prologue also marks out the text’s dramatic, verbal construction: “[Je l’]appelle quadrilogue pour ce que en quatre personnages est ceste oeuvre comprise, et est dit invectif en tantqu'il procede par maniere d'envaïsement de paroles” [I call it Quadrilogue because this work is divided between four characters, and invectif because it proceeds by assaults of speech]. ${ }^{52}$ In terms of further crossover between the array of printed texts brought out by Mansion in the 1470s/80s and the themes of the QI, the anonymous Abuzé en court is also suggestive. Cayley describes this allegorical text, in which the Abuzé-figure’s corruption by courtly vices is revealed, as “probably directly inspired by the anti-courtly polemic of Chartier's [De vita curiali]”. ${ }^{53}$ The Abuzé is in one case linked to Chartier through manuscript transmission, ${ }^{54}$ while the French Curial is anthologized seven times with the $Q I$ in manuscripts. ${ }^{55}$ The Abuzé, like the QI and the Controversie/Débat, is structured around verbal dialogues. Through these dialogues, the corrupt way of life at court is exposed and critiqued: “en grant dangier ly homs se vit / Qui a present a le court vit” [That man sees himself in great danger, who presently lives at the court]. ${ }^{56}$ Mansion's Abuzé and QI resemble one another visually; each is printed in folio format, with one 
large column of text beginning with a hand-inserted capital. The Controversie/Debat were similarly printed in folio. ${ }^{57}$

In addition to Mansion’s version, the Abuzé was printed in 1484 in Vienne-en-Dauphiné by Pierre Schenck, an edition which also came hot on the heels of a QI print. The Vienne market for printed books was established by Schenck's predecessor Johann Schilling ${ }^{58}$ during the 1470s. Schilling printed a total of 15 texts in Vienne, of which three were in French, notable given that Schilling, a native of Bâle, apparently had little knowledge of the French language. ${ }^{59}$ Two of his three French texts were related to Chartier: the QI and the Complainte d'ung amoureux, now better-known by its common manuscript rubric, which imitates Chartier's Belle Dame sans mercy, as La Belle Dame qui eut mercy (hereafter BDQEM), an amatory debate poem between a lover and his (prospective) lady. ${ }^{60}$ Thus, by around 1484, three Chartier-related texts had appeared on the Vienne market, two of which were also issued close together by Mansion, in Bruges. Of these three, Schilling’s QI and Schenck’s Abuzé - which, like Mansion’s Bruges editions, resemble one another in terms of textual presentation and layout - are concerned with critiquing corrupt and self-seeking courtly values, and reasserting the importance of good governance of the self and society. The BDQEM perhaps appears the odd text out in this trio; however, its widespread manuscript assumption into the Querelle de la Belle Dame sans mercy, not to mention its debate format, associate it more generally with Chartier's ethical poetics. ${ }^{61}$

There is evidence that many of the shorter texts issued by Mansion in Bruges were read as part of Sammelbände of printed material. In addition to two probable contemporary Sammelbände containing Mansion’s QI (which I shall consider shortly) one further suggestive volume can be traced. Copies of three Mansion texts - L'Abuzé (CIBN A-9), Les Advineaux amoureux (CIBN A-22), and Les Evangiles des quenouilles (as yet uncatalogued by CIBN) - 
although now split, were purchased bound by the BnF from the library of the Comte de MacCarthy Reagh in $1817 .{ }^{62}$ The sale catalogue describes the texts as works which "paroissent avoir été imprimés dans la vue de les réunir en un volume”. ${ }^{63}$ Their provenance pre- this sale is identical, and goes back to the late 17th- or early 18th century; it is certainly possible that they were once an early collection. There are now two extant copies of Colard Mansion's 1477 QI. Both came into the hands of BnF librarian and collector Joseph Van Praet during the 19th century. One copy had been in the BnF since 1808, the second belonged the Baron d'Heiss until 1786, when Van Praet bought it from him. At Van Praet's death in 1837 it was bequeathed to the Openbare Bibliotheek, Brugge. Both were almost certainly constituent items in Sammelbände of 15th-century printed Brugeois material.

The copy of the QI bought by the BnF in 1808 was originally bound with a copy of William Caxton's edition of Raoul le Fèvre’s Roman de Jason, printed in Bruges in or around 1476. Van Praet describes the "ancienne reliure en bois", the old wooden binding, in which these two texts were found before he split them, presumably dating to some time in the late 15th or 16th centuries. ${ }^{64}$ The $Q I$ was probably the first text in this volume; in the top margin of its opening page, it bears its 15th-century Flemish owner’s handwritten inscription: “Desen boockhort toe lisken van banselen” [This book belongs to Lisken Van Banselen].

Interestingly, in the light of recent critical trends, this ex-libris suggests female ownership of the $Q I$ - a text which has, of course, come to be recognized as a key part of a broad "profeminine prise de position by Chartier ... [which] informs [his] entire production”, ${ }^{65}$ as well as a politically-motivated critique. Goodman notes of Caxton's Jason that it too displays overtly profeminine aspects when compared to its sources; it "alternates between knightly deeds and 
amorous adventure ... [is] well supplied with expressive and adventurous female characters, [and] ... Lefèvre does his best to rehabilitate Medea.”66

Pairing the QI with Caxton's Jason in a Sammelband is also interesting in the light of Mansion’s Débat/Controversie; like Miélot’s translations, le Fèvre’s Jason was a Burgundian production, commissioned by Phillip the Good, who established the Order of the Golden Fleece in 1430, and for whom the stories of Jason were important in establishing the mythical ancestry of his illustrious ducal house. As Goodman notes, the lavish 1468 wedding celebrations of Phillip’s heir, Charles the Bold, to Margaret of York included pageants portraying Jason and Hercules, an event which Caxton's Jason might well have recalled. ${ }^{67}$ The 1477 volte-face in Burgundian political fortunes caused the dynasty to shift suddenly from displays of wealth, culture and power centered on a strong male figurehead, to a position of weakness and insecurity. Binding Caxton’s 1476 Jason alongside Mansion’s 1477 QI acts out an uneasy juxtaposition of Burgundian greatness with the unsettling social and political effects of Charles the Bold's untimely death.

The second extant copy of Mansion's QI is now found in the OB Brugge. When Van Praet acquired this text from the Baron d'Heiss in 1786, it too was part of a larger bound volume of Mansion pieces. This volume, which I term the "recueil Heiss”, may have been another contemporary Sammelband, or, more probably, a larger, later collection based upon one or more core early collections. The two published descriptions of it are frustratingly vague. ${ }^{68}$ The 1779 description gives no detail as to the age and format of the binding: “un épais volume in-folio, imprimé en caracteres gothiques ... Il s'est trouvé que ce volume contenoit huit Editions faites à Bruges par Colard Mansion” [a thick, folio volume, printed in gothic characters... this volume contained eight editions printed in Bruges by Colard Mansion]. ${ }^{69}$ 
This volume contained the following Mansion texts (in order of appearance): ${ }^{70}$

1. Le Jardin de dévotion (Pierre d'Ailly)

2. La Doctrine de bien vivre (Jean Gerson)

3. L'Art de bien mourir

4. La Controversie de noblesse (Bonaccursius de Montemagno, also listed as 'da Pistoia', trans. Jean Miélot)

5. Le Débat entre trois chevalereux princes (Latin adaption of Lucan by Giovanni Aurispa, trans. Jean Miélot)

6. Le Doctrinal du temps présent (Pierre Michault)

7. Les Adevineaux amoureux

8. Le Quadrilogue invectif (Alain Chartier)

Van Praet directed that upon his death (which occurred in1837) his personal collection of Mansion prints (numbering considerably more than those here discussed) be distributed to two different libraries:

lorsque le possesseur actuel n’existera pas, les éditions de Colard Mansion qui lui appartiennent, et qui manquent à la Bibliothèque du Roi [now the BnF] seront réunies à celles qui s’y trouvent déjà; les autres seront déposées à la Bibliothèque de sa ville natale [now the OB Brugge]. ${ }^{71}$

[When the present owner of these books is no more, the Colard Mansion editions which belong to him and which are currently not owned by the BNF will be added to those which that library already holds. The others will be placed in the library of the town of his birth, i.e. Brugge.] 
One BnF copy of the Mansion Adevineaux, now shelfmarked Rés Ye 186 (CIBN A-23) ${ }^{72}$ and their only copy of the Doctrinal, now shelfmarked Rés Ye 89(CIBN M-355) are catalogued as a legacy from Joseph Van Praet, previously owned by Heiss. On the opening folio of each text, the same early hand has inserted the text's title in red ink in the middle of the upper margin. These two texts, then, apparently had the same early owner who handwrote their titles in a uniform position. In addition to its title, this copy of the Adevineaux also bears the signature “Thomas” in an early hand, accompanied by very distinctive pen flourishes, in two places. A very similar red handwritten title and an identical “Thomas” signature are also found in the OB Brugge’s copy of Chartier’s QI, which it received as a legacy from Van Praet, on the opening and closing folios respectively. These three copies originally formed the final three texts in the recueil Heiss. These texts were clearly kept together at some point early in their history; all three were titled in red, and two were also signed uniformly by “Thomas”.

The 1779 description of the recueil Heiss provides further information about “Thomas”, for it transcribes a distinctive ownership note copied by hand onto the final folio of the Heiss Débat entre trois chevaleureux princes: “Ces presens livres sont a moi, Léonard Thomas, Prêtre. Qui les trouveray qui[l] les rende \& je pairay le vin” [These present books belong to me, Leonard Thomas, priest. Whoever finds them, let him give them back to me and I'll buy him some wine]. ${ }^{73}$

This ownership note can be seen clearly today on the final folio of what is now BnF Rés D.862, the volume which contains the sole BnF copy of the Débat (CIBN B-612). It is here accompanied by an identical “Thomas” signature and pen flourishes to those which appear in the Adevineaux and QI discussed above, and it identifies this copy of the Débat as that which constituted part of the recueil Heiss in 1779, and which obviously formed part of Léonard 
Thomas's early collection of Mansion texts. Also owned by Léonard Thomas was the copy of the Art de bien mourir which is now the second text in Rés. D.862; it too bears his distinctive signature at its close. ${ }^{74}$ At the very least, Thomas's collection of texts, as identified through his signature, must have comprehended the BnF Débat which bears his ownership inscription, the copy of the Adevineaux which is now BnF Rés Ye 186, the OB Brugge QI, the BnF Art in Rés. D.862, and very possibly the BnF Doctrinal as well. ${ }^{75}$ Chartier's text, then, was certainly being read by one early reader in the context of Mansion’s broader printed output.

The Querelle de la Belle Dame sans mercy in Lyon

As has been frequently noted, the town of Lyon on the rivers Rhône and Saône saw an explosion in printed vernacular books at the end of the 15 th century. ${ }^{76}$ Its geographical location afforded it a web of trade links with most of western Europe, and it was known for its mercantile activities, including frequent foires attracting traders from far afield. ${ }^{77}$ The beginnings of printing in Lyon in the early 1470s foreshadow key elements of its future success. Barthélemy Buyer, a local businessman, hired Guillaume le Roy, a printer from Liège in the Low Countries, to pioneer the new technology in Lyon, producing a range of books designed to suit the different tastes, professional orientations and disposable incomes of the town's inhabitants. ${ }^{78}$ Until 1485 , printers were afforded tax exemption by the town, attracting a large number of book-producing artisans from different areas of Europe. Fau et al document the tightly-knit networks of exchange and co-ownership in materials and premises which swiftly took hold in Lyon among its population of printers. These networks were facilitated by intermarriages, inheritances, and geographical proximity (the printers' district in Lyon was situated on the "presqu'île”, a slim strip of land between the town's two rivers). 
Among the most successful of the earliest Lyon printers is the still-anonymous "ICD", ${ }^{79}$ who introduced a series of vernacular texts into the Lyon marketplace c. 1489-92. Among these are three by Chartier (La Belle Dame sans mercy (BDSM), La Complainte contre la mort, Le Lay de paix), and three more which have firm associations with Chartier in manuscripts: the BDQEM, L'Hôpital d'amours and Le Songe de la pucelle. Of these three, the Hôpital and the $B D Q E M$ are commonly featured in manuscripts as component parts of the Querelle de la Belle Dame sans mercy. ${ }^{80}$ Four of a possible nine manuscripts collect the Songe with Chartier works, two of which four include the BDSM and Querelle-texts. ${ }^{81}$ Chartier's own Complainte, too, is often anthologized with the BDSM and Querelle-texts. ${ }^{82}$ The ICD also issued - among other items - several debate-texts, a collection of Demandes et réponses d'amours, and two editions of Dits et ventes d'amours. ${ }^{83}$ These short works (those mentioned here range from 6 to 28 folios), all printed in quarto format, appeared alongside larger, more ambitious books by the same printer, including Martin le Franc’s Champion des dames, whose defence of female virtues also resonates with the themes of the BDSM and Querelle. ${ }^{84}$

I suggest that the manner in which the ICD issues these texts forms a response to the phenomenally popular Querelle de la Belle Dame sans mercy, transmitted in various forms in more than 30 manuscripts in the course of the 15 th and early 16 th centuries. ${ }^{85}$ McRae, in an important article, has recently explored the booklet construction of some Querelle-manuscripts, suggesting that many were "constructed item by item from booklets conceived with the intention of disposability," as well as appearing in bespoke or pre-planned codices. ${ }^{86}$ She outlines the speculative purchase of manuscript texts in booklet form, perhaps at different times and from different sources, to be followed later by retrospective binding at the instigation of the owner, as a possible feature of many Querelle-manuscripts. Cayley and McRae have also drawn attention 
to the ways in which intertextual relationships between various works constituting the Querelle de la Belle Dame sans mercy are often encoded through construction, layout and decoration of manuscripts. ${ }^{87}$ Fribourg, Bibliothèque Cantonale et Universitaire MS L. 1200, for example, features rubrics which sequence its Querelle-texts in a numerical order (e.g. "ly seconde livre”, "ly tier livre”), and refers to "la belle dame” as central protagonist in each text. ${ }^{88}$ BnF, fr. 2230 boasts a carefully-organized design scheme in which a system of decorated borders and capitals are used alongside rubrics to link Querelle-contributions together into one sequential liure or group.

The approach to gathering booklets of Querelle-texts described by McRae obviously intersects fruitfully with the reader-led creation of printed Sammelbände. The paratextual features of the ICD’s Querelle-texts suggest that he, like many scribes and annotators, presented these works using regular and corresponding systems of organization and decoration. These give a sense of visual uniformity to his printed works, enhanced by his distinctive typeface, encouraging readers to perceive them as a matching set. The ICD's BDSM, BDQEM and Songe are all presented using an identical format. The printer opens all three with a woodcut illustration in the center of the page, and the title of the work above it. The verso contains the same woodcut illustration, but without the title, and the opening folio of text begins with the rubric "Sensuit..." or “Cy commence...” ['here follows' or 'here begins'] followed by the title (for the BDSM and the Songe, see figs. 2 and 3). In each case, the text is presented in one column in the center of the page, and the rubric is situated at the opening of this column. The woodcuts used to illustrate the three texts were taken from the series used in Jean du Pré of Lyon’s 1489 Pierre et la belle Maguélonne. The ICD uses a series of images by (presumably) the same engraver, taken from the same long narrative, with corresponding visual aesthetics to illustrate this series of texts. His 
presentation of the Hôpital is almost identical (see fig. 4); the only difference is that here, he uses two woodcuts (rather than one, repeated) on recto and verso of the title-page, from a different source. Both Hôpital woodcuts depict an identically-designed image of Cupid, however, and both originally occurred in the ICD’s Champion edition (occurring on Ff. a.vii v and b.v r of that text).

The layout of these texts, then, and the associations most of their woodcuts have, suggest uniformity of presentation. The BDSM is linked through layout to the BDQEM - mirroring the latter's widespread incorporation into the Querelle - at the close of which poem the Lady abruptly changes her hostile tone and accepts the Lover. Titling the poem with reference to the BDSM, as many manuscript copies do, conceptualizes it as a move in the Querelle de la Belle Dame sans mercy, a reprise of the discussion between Chartier's Lover and Lady. ${ }^{89}$ It effectively re-writes the end of Chartier's poem to give a lady "qui eut mercy” [who had mercy], unable to resist the "beau parler” [attractive language] of her lover, instead of being rendered suspicious by it. However, the ICD also includes the Songe in this group, in which, as Cayley has shown, it is suggested through the allegorical figure of "Honte” [Shame] that "la Pucelle” [the young girl] should adopt precisely the distrust of courtly rhetoric displayed by the $B D S M$, rather than the enthusiasm for romantic intrigue suggested by “Amour” [Love]. Honte's advisory role in the poem is foregrounded by the ICD through his woodcut, which depicts a woman in bed visited by a second woman; these figures are labelled pucelle and honte by the printer. The Songe, BDSM and $B D Q E M$ all explore the positions in which women are placed when pressed to return sudden (often unsolicited) declarations of love. The topic of courtly love is exploited further by the ICD through his inclusion of the Hôpital - one of the most widely-transmitted Querelle-texts in manuscripts - into his printing program. Although its woodcut-source differs from those of the 
foregoing texts, it links thematically with them as the poem’s narrator famously views Chartier's own tomb beside that of the Belle Dame’s lover. In doing so it promotes its own importance as a response to the BDSM. The poem also memorializes Chartier, citing his name as the ultimate example of poetic skill, ${ }^{90}$ an advertisement for other texts by or otherwise associated with him. Finally, its woodcut-source also emphasises the relevance of Le Franc's Champion to the issues raised by the Querelle; as McRae notes, ${ }^{91}$ Le Franc makes explicit reference to the Hôpital within the Champion, and the ICD cements this intertextual connection visually.

Uniformity of a different kind occurs in the ICD’s presentation of Chartier's Complainte and Lay de paix. For these texts (and many others, e.g. Les Demandes and Les Ventes) the ICD uses the fashionable oversized calligraphic "L" as focal point for the title page. Following the title pages, these texts are then laid out like the BDSM, with an incipit in the center of a single column, followed by the text. Hillard identifies the ICD as one of the first printers in Lyon to follow the trend for a calligraphic "L", which had begun in Paris. ${ }^{92}$ The same "L" was, as we have seen, also copied by Pierre Le Caron for use in his 1489 pioneering collected Chartier edition, Les Fais. In this way, the ICD’s Chartier texts are also linked visually, through fashionable printing styles, to contemporary developments in printing Chartier outside of Lyon. As with Mansion texts in Bruges, some evidence remains which suggests that short texts issued by the ICD and his Lyon contemporaries were gathered in Sammelbände. The British Library holds an ICD copy of the Lai de paix and Complainte, now bound separately. Their bindings are identical, suggesting that the texts were placed in them by the same owner. Both texts are six folios long; however, the post-medieval binder has had to "pad out" the end of each volume with blank leaves; this feature lends weight to my suggestion that placing a hard binding on one six-folio text was an impractical task. In both prints, distinctive yellow-ink rubrication 
has been applied to the calligraphic " $\mathrm{L}$ " on the title page, and to capital letters throughout the text. The pages of the Lai have been stained brown in places, and a similar brown stain appears on F. a.ii of the Complainte. These features combine to suggest that this ICD Lay de paix and Complainte may, at an early stage in their history, have been bound together. Further possible evidence of a Sammelband gathering ICD Chartier-related texts is the volume sold by JeanPierre Imbert Chastre du Cangé in 1733, now dismembered in the BnF. ${ }^{93}$ This collection contained ten texts by the ICD, including the Songe, the BDSM, the BDQEM and the Lay de paix. ${ }^{94}$ How old their binding was, however, cannot now be determined. ${ }^{95}$

I have thus far concentrated upon the ICD because his program of textual presentation created visual and thematic links for his consumers between the texts he issued, and thus invited a reading strategy which searched out intertextual resonances. This, I have argued, in some respects mirrors the manuscript contexts in which Chartier texts were often transmitted during the 15th century. Moving focus outwards to consider the Lyon marketplace more broadly reveals a raft of editions of related texts available in the same marketplace at the close of the 15th century, and which argue for the commercial viability and intense popularity of these works. Gaspard Ortuin issued an edition of the Hôpital c. 1490; Ortuin’s title page format bears little resemblance to that of the ICD, differentiating the two rival editions of the text for their potential buyers. His title page doubles as incipit, using a decorated capital “C” (“Cy commence...”), with a woodcut on the verso. Both capital "C" and woodcut were from his recent edition of Breydenbach’s Pelerinage a iherusalem. ${ }^{96}$ At around this date, Ortuin also worked in partnership with Pierre Schenck, printer of the Abuzé in Vienne, who adopted the name Boutteiller in Lyon. One of the woodcuts initially used by Schenck/Boutteiller in his Vienne edition of the Traité des eaux artificielles soon after appears in Lyon, illustrating a 1491 print of the BDQEM by Mathieu 
Huss (a text which Schenck/Bouteiller would probably have known due to its earlier Vienne impression by Schilling). Huss also employed a distinctive border which had its origins in Vienne to decorate this text. ${ }^{97}$ A copy of the Abuzé en court had been brought out anonymously in Lyon c. 1484/5, upon whose illustrations Schenck/Bouteiller based his Vienne edition’s woodcut cycle. ${ }^{98}$ Commercial and artistic contacts between printers thus forge links between the Vienne market and Lyon. One of the two 15th-century Sammelbände now in Jena comprises three Lyon texts: a set of Demandes d'amour (Schenck/Bouteiller), du Pré's Pierre de Provence, and an anonymous Hystoire et pacience de griselidis, a text also issued by Schenck/Bouteiller in Vienne and Lyon. ${ }^{99}$ The 15th-century owner of both Jena volumes has been traced to Lyon, ${ }^{100}$ suggesting that gathering short, vernacular texts together in Sammelbände did indeed form part of Lyonnais practices of book consumption and marketing.

Alongside the ICD and Huss BDQEMs, further editions of the poem were brought out in Lyon c. 1495 by Pierre Maréschal and Barnabé Chaussard, and post-1497, possibly by Jean de Vingle. Both of these editions employ the same woodcut illustration of a woman and a man to illustrate the text. This illustration, originally of Jason and Medea, had been used by Le Roy to illustrate his c. 1487 Lyon edition of the Roman de Jason; here it incorporated a panel displaying an ox, a dragon and the golden fleece which has been removed for the BDQEM edition. De Vingle's BDQEM uses similar presentation strategies to the ICD: a grotesque, calligraphic "L" is used to form the "La" of the title-page while the Jason woodcut is printed on its verso. The calligraphic "L” is, however, very different in design to that of the ICD. ${ }^{101}$ Maréschal-Chaussard preferred a totally new form of title page, with the BDQEM's title in large textura-style letters, and a woodcut directly beneath it. In addition to producing a BDQEM (issued twice c.1495) Maréschal-Chaussard also issued another BDSM-related text, L'Amant rendu cordelier à 
l'observance d'amours, ${ }^{102}$ and the first copy of Chartier's Breviaire des nobles (BN) to be printed in Lyon, both c. 1500. The issue of these texts by Maréschal-Chaussard places them in a Lyon marketplace which included copies of Chartier’s BDSM, Lay de paix and Complainte (ICD), two of the Hôpital (ICD and Ortuin), one of the Songe (ICD) two of the Abuzé (anon., and Martin Havard c. 1494) and several of the BDQEM (ICD, Huss, de Vingle, MaréschalChaussard). These Chartier pieces, and texts associated with him, were often marketed by Lyonnais printers as uniformly-designed quarto books, a feature which would encourage collection and mise-en-recueil on the part of consumers. The ICD appears to have established a particular commercial interest in these texts. His BDSM, BDQEM, Hôpital and Songe are presented visually as a matching set of pamphlets, as are his Complainte and Lay de paix. His presentation strategies reinforce intertextual connections within this series, while the choice of the Champion des dames as source-text for the Hôpital's woodcuts also draws Le Franc's defence of women directly into its orbit. Robert Foucquet, Jean Crès and the Breviaire des nobles

While the production of Chartier texts in Lyon can be contextualized in terms of the town's extraordinary boom in vernacular printed books, the print with which I conclude was produced in a different geographic and economic context. Towards the end of 1484, Robin Foucquet and Jehan Crès were set up as printers in the town of Bréhan-Louédac, Brittany, by a local nobleman, Jean de Rohan, Seigneur du Gué-de-L'Isle. ${ }^{103}$ These printers brought out a much more extensive and cohesive repertoire of texts than any yet issued in Brittany, a repertoire which included Alain Chartier. During the year 1485, the Foucquet-Crès atelier rapidly issued a series of seven short French texts (6-14 folios in length) which included Chartier's BN, plus the 
Coutumes de Bretagne, the Mirouer d'or de l'âme pécheresse (58 folios), the Vie de Jésus-Christ (154 folios) and the Danse des aveugles (44 folios). ${ }^{104}$

Only one copy of the Foucquet-Crès $B N$ now survives, in BnF, Rés Ye 1154. This book is a collection of six of the possible seven short Bréhant-Louédac prints. ${ }^{105}$ On arrival in the library, it formed part of a larger collection of Foucquet-Crès material, which also contained the Vie, the Mirouer and the Secret des secretz. ${ }^{106}$ When these texts were originally bound together is impossible to say; it seems likely, however, that at least some of the six short texts which now make up Rés Ye 1154, including the BN, were kept together at an early date. Several different 15th-to-16th century hands have made notes and scribbles at various points throughout the texts, all of which fit neatly into the current page margins, suggesting that they were all exactly the same size when annotated (and that they have not been trimmed since). One of the longer manuscript notes comprises an accurate citation, copied onto the final folio of the $B N$, of the first few lines of the Trespassement nostre dame, which is found immediately before the Songe and the $B N$ in the current arrangement of the volume. These features would suggest that the $B N$ and the Trespassement at least may have been kept together at an early stage in their history.

La Borderie has suggested that Foucquet-Crès’s business plan may have involved marketing a series of "handbooks" comprising short vernacular pieces including devotional texts (Trespassement, Oraison, Vie, Lois), material to equip readers with legal and interpersonal savoir-faire (Secret, Coutumes), and conduct guides (Songe, Patience, BN). ${ }^{107}$ Consumers would be able to mix and match texts; for example, a household containing a young son and daughter might want to collect the $B N$ and the Songe as exempla in good conduct for each gender. The proverbial sayings incorporated within the Songe might play into this presentation as didactic literature; they provide "soundbites” of wisdom which a young reader could take away from the 
text. $^{108}$ The repeated lines of each ballade in the $B N$ could equally have this effect. A household in which a young woman was about to be married might consider the Patience de Griseldis subtitled Lexemplaire des fames mariees - useful reading matter. Certainly, it was often anthologized in manuscripts in this way; it appears three times with the Ménagier de Paris and four with the Livre du Chevalier de la Tour Landry pour l'enseignement de ses filles. ${ }^{109}$

As La Borderie notes, "les impressions ... se ressemblent absolument: même format ... même papier avec même filigrane: on dirait le même livre” [the printed books resemble one another absolutely: the same format, the same paper with the same watermark: they could be the same book]. ${ }^{110}$ To this, I would add that each features an almost identically-worded colophon, commencing “cy finist...” [here ends], and giving date, name of printers and patron. This uniformity of presentation may be partly due to the fact that Foucquet and Crès were début printers in 1485; elaborate design features may have been beyond their scope. However, the net result is a collection of short booklets which (like those issued by the ICD) belong together visually in a series, an effect which may well have been commercially-motivated, aimed at fostering didactic connections between the texts.

A second context for the Songe, $B N$ and Patience trio, however, is found in manuscript presentation. Four extant manuscripts collect the Songe with Chartier's BN. ${ }^{111}$ Cayley discusses the way in which the Sion manuscript's rubrics explicitly call attention to the "sense of community and interplay of these texts”, highlighting the scribe’s presentation of the Songe as an intertextual partner-piece to the other items in the manuscript. ${ }^{112} \mathrm{I}$ have already discussed the ways in which the Lyon Songe is presented intertextually by the ICD alongside the BDSM, BDQEM, Hôpital, Lay de paix and Complainte, and the relevance this may have for Chartier's 
anti-courtly, pro-feminine stance. ${ }^{113}$ Its impression by Fouquet-Crès alongside the Patience and the $B N$, I suggest, forms a further exploration of this stance. ${ }^{114}$

The Patience appears several times in manuscript collections alongside explicitly profeminine material, including the Roman de Melibé et Prudence, and, on one occasion, Le Fèvre’s Livre de leesce (Vatican, Fonds Reine Christine Reg. MS 1519). ${ }^{115}$ In Arsenal MS 2076, as Cayley notes, it appears beside the Debat entre bouche medisant et femme deffendant, which in turn appears once collected with Chartier pieces, including the Bréviaire. ${ }^{116}$ In Valenciennes, BM MS 417, the Patience is anthologized with the $B N$, the Débat de reveille-matin and the Hôpital. ${ }^{117}$ The Débat des deux seurs, another text discussed by Cayley due to its frequent appearance with the BDSM and Querelle, also appears in Valenciennes 417. This piece is anthologized twice with the Songe: in BnF, fr. 25553 and Arsenal 3523, which also contains the $B N$. The Songe, Patience, and $B N$, then, are a trio of texts whose potential associations, in the minds of some consumers, might go well beyond conduct literature.

Conclusion

In printing the $B N$, Songe, and Patience as a set, I have suggested that Fouquet and Crès’s activity may be situated alongside the production of specific types of Chartier manuscript anthology, of which Arsenal 3523 or Valenciennes BM 417 are good examples, manuscripts whose central themes pivot around a discernible contribution to the Querelle des femmes and the related problem of sincerity in courtly discourse, most often through setting up intertextual dialogue between texts by Chartier and by others. In this sense, Chartier is an author whose dissemination in manuscript and print in the late 15th and early 16th centuries throws into extremely sharp relief some of the continuities between the two media for which I have argued throughout this chapter. These continuities, I have argued, are visible not just in the presentation 
of large, collected Chartier volumes such as the Fais, but also in the overlooked production of specific Chartier texts in printed form, and the ways in which these individual texts interact with others found on the same marketplace at roughly the same time and in the same place, whether issued by a single printer or more than one. Cayley has described manuscript books containing Chartier texts as "material spaces of play"; ${ }^{118}$ this description could equally well be applied to printed texts. Printers, I have suggested, linked texts visually and paratextually through page layout, design, woodcut source and placement, all features which provide an interpretative structure through which a reader might approach a text, and which can encourage that reader to consider texts as interconnected with one another, able to speak to one another, rather than as individual, stand-alone “books”. Tracing and re-assembling, where possible, the potential connections forged by readers and printers between texts, and setting them alongside our knowledge of the way in which Chartier is often presented in manuscripts, allows us to more fully comprehend the ways in which Chartier’s myriad early readers took readerly and interpretative possession of his work. It also allows us to appreciate the extent to which particular printers participated in and facilitated this action.

The way in which I have chosen to present this material has, inevitably, focused upon particular places -Brugge, Lyon, Brittany, Paris. At the close of this chapter, then, it will be salutary to foreground the limitations, as well as the advantages, of this approach. Firstly, the links between manuscript and print which I have highlighted in each case - although important are certainly not the only ones which can be drawn between the books I have discussed. Fouquet and Crès’s printed pamphlets, for example, could also be seen to fit in with the work of contemporary printers from different locations, such as those active in Vienne, or in Lyon, where the Patience and Songe had been printed alongside several Chartier texts, and where an 
individually-printed copy of the $B N$ was also to become available in 1500 . Geographical locations such as Lyon or Brugge were not isolated or "sealed off" areas, and printed texts could, and did, move from their initial geographical location. In this way, methods of consumption of printed texts might influence each other as much as they influenced, and were influenced by, manuscript books. Secondly, in choosing to focus closely on the output of particular printers in particular places, there are, inevitably, books which I have not discussed. The BDSM, for example, is not only printed in Lyon; editions of this work are issued in Paris by Nicolas de la Barre c. 1500 and by Richard Auzoult in Rouen c. 1504-5; both would bear further discussion. The $B N$, likewise, is also issued in Paris by Guillaume Nyverd in 1515. Antoine Vérard remains, apparently, the only printer to issue the Débat des deux fortunés d'amour (as part of his Jardin de Plaisance) until Galliot du Pré; Chartier's appearance in the Jardin also, no doubt, merits more investigation than I have been able to give here. Examining Chartier's appearance in print, then, reveals an author whose output is widely drawn upon by many early printers in different geographical and cultural contexts, and whose presence in print has much to tell us about latemedieval book production, marketing and readerships.

Olivia Robinson Brasenose College, Oxford

\footnotetext{
${ }^{1}$ My thanks are due to the staff of all the libraries in which I have worked, but most particularly to LudoVandamme of the Openbare Bibliotheek Brugge and to Nicolas Petit of the BnF for their generous assistance.

${ }^{2}$ See Emma Cayley, Debate and Dialogue: Alain Chartier in his Cultural Context (Oxford, 2006); "Poetry, Politics and Mastery in the Manuscript Tradition of Alain Chartier," in Chartier in Europe, ed. Emma Cayley and Ashby Kinch (Cambridge, 2008), pp. 75-89; “Debating
} 
Communities: Revealing Meaning in Late Medieval French Manuscript Collections,” Neuphilologische Mitteilungen 105 (2004), 191-201; “Collaborative Communities: the Manuscript Context of Alain Chartier’s Belle Dame sans mercy,” Medium Aevum71 (2002), 26640; and "Polyphonie et dialogisme: Espaces ludiques dans le recueil manuscrit," Le recueil à la fin du moyen âge, ed. Tania Van Hemelryck and Stefania Marzano (Turnhout, 2010), pp.47-60;

Le Cycle de la Belle Dame sans mercy, ed. David Hult and Joan McRae (Paris, 2003); Joan McRae The Trials of Alain Chartier's Belle Dame sans mercy: The Poems in their Cyclical and Manuscript Context (unpubl. PhD diss., University of Virginia, 1997); and "Cyclification and Circulation of the Querelle de la Belle Dame Sans Mercy,” in Chartier in Europe, pp. 90-104; David Hult, “Alain Chartier: Authorial or Scribal Culture?,"Revue belge de philologie et d'histoire 83 (2005), 769-83; Adrian Armstrong, The Virtuoso Circle: Competition, Collaboration and Complexity in Late Medieval French Poetry (Arizona, 2012). For extant Chartier manuscripts, of which there are approximately 190, see James Laidlaw, The Poetical Works of Alain Chartier (London, 1974) and "The Manuscripts of Alain Chartier," The Modern Language Review 59 (1966), 188-98, supplemented by Cayley, “Debating Communities” and Debate and Dialogue, Appendix B.

${ }^{3}$ For recent assertions of the importance of material contexts to medieval texts, see e.g. Keith Busby, Codex and Context: Reading Old French Verse Narrative in Manuscript (Amsterdam, 2002), Le recueil au moyen âge: le moyen âge central, ed. Olivier Collet and Yasmina FoehrJanssens (Turnhout, 2010) and Adrian Armstrong, Technique and Technology: Script, Print and Poetics in France 1470-1550 (Oxford, 2000).

${ }^{4}$ The most obvious example of this tendency is, of course, the Querelle de la BDSM, on which see Cayley, Debate and Dialogue, ch.4 and Hult/McRae, Le Cycle. 
${ }^{5}$ Ardis Butterfield, “Epilogue,” in Le Recueil au moyen âge, pp. 269-77, at p. 269.

${ }^{6}$ Cayley, “Poetry, Politics,” p. 87.

${ }^{7}$ The impulse to collect Chartier works in a single-author edition, first issued by Pierre Le Caron in 1489 and then repeatedly thereafter, has been recently investigated by Hult, "Authorial or Scribal.” I therefore limit my discussion of these volumes here in favor of less-well-canvassed Chartier prints.

${ }^{8}$ See Mary-Beth Winn, Antoine Vérard, Parisian Publisher (Geneva, 1997).

${ }^{9}$ Term used by Jane Taylor, The Making of Poetry: Late Medieval French Poetic Anthologies (Turnhout, 2007), p. 234.

${ }^{10} \mathrm{BnF}$, Rés.Vélins 582. On illuminating Chartier, see Serchuck in this volume.

${ }^{11}$ See CIBN C-267, 268 and 269 for up-to-date information on these volumes.

${ }^{12}$ Entitled Les Faiz et dictz du feu de bon memoire Maistre Alain Chartier and Les Euvres feu Maistre Alain Chartier respectively; on Galliot's shift from faiz to œuvres, and the classical prestige he lends to Chartier by the use of the latter, see Nancy Freeman Regaldo, "Gathering the Works: The Euvres de Villon and the Intergeneric Passage of the Medieval French Lyric into Single-author Collections,' L'Esprit créateur 33 (1993), 87-100, p. 88. Du Pré’s 1529 CEuvres is the first Chartier edition to use roman type, as opposed to blackletter, for his vernacular texts. On the presentation of this volume as part of a nostalgic "set” by Galliot, alongside the Roman de la Rose and the Champion des Dames, see Helen Swift, Gender, Writing and Performance: Men Defending Women in Late Medieval France (Oxford, 2008), p. 80.

${ }^{13}$ See discussion by James Laidlaw, “André du Chesne’s edition of Alain Chartier,” Modern Language Review 63 (1968), 569-74.

14““André du Chesne,” pp. 569-70. 
${ }^{15}$ Chartier's De vita curiali frequently circulated in French translation, Le Curial: see Cayley, Debate and Dialogue, pp. 98-99. Some of his Latin works were added by du Chesne to the 1617 collected edition. See Laidlaw, “André du Chesne,” p. 570.

${ }^{16}$ See Laidlaw, “André du Chesne,” pp. 569-70.

${ }^{17}$ Unfortunately, space does not permit me to discuss this volume here; see Taylor, Making of Poetry, ch. 4, esp. pp. 235-6.

${ }^{18}$ Denise Hillard, “Histoires d'L,” Revue françaised'histoire du livre 118-21 (2003), 79-104, p. 89.

${ }^{19}$ Cf. Hult’s argument that Fais (“deeds” or “makings”) need not mean precisely "works by” Chartier, “Authorial and Scribal,” p. 777. Hult reads the move to fais et dits as a title-page formulation, introduced by Le Noir in 1523, as a more concrete assertion of Chartier's authorship; however, the phrase fais, dits et ballades was used in colophons from Le Caron's 1494 edition.

${ }^{20}$ See Hult, “Authorial or Scribal,” p. 775 and n.9. However, as Hult notes, the very ubiquity of Chartier's presence in manuscript anthologies - even though unacknowledged by name paradoxically points "to the prestige accorded Chartier and ... [his] poetics”, p. 777.

${ }^{21}$ As was the title page itself; cf. Armstrong, Technique and Technology, pp. 5-9 and R. Hirsch, “Title Pages in French Incunables 1486-1500,”Gutenburg-Jahrbuch (1978), 63-6.

${ }^{22}$ See, for example, the Trepperel-Jehannot c. 1515 title-page, which boasts alternate red and black printed words and a woodcut.

${ }^{23}$ See Peter Haidu's comments on the resonance of Chartier's name, connecting him through pun both to charters, notaries and thus governmental paperwork, and to humble cart-driving, The 
Subject Medieval/Modern: Text and Governance in the Middle Ages (Stanford, 2004), pp. 31427.

${ }^{24}$ Hult, “Authorial or Scribal,” p. 775.

${ }^{25}$ Ibid., 773-4; 779.

${ }^{26}$ See particularly discussions of collected editions of Chaucer in print by Alexandra Gillespie, Print Culture and the Medieval Author: Chaucer, Lydgate and their Books (Oxford, 2006): "the print producer describes a stable identity for the book, one derived from the person of the author and the idea of his works that may accommodate all sorts of old vernacular texts”, p. 137.

${ }^{27}$ As has recently been suggested by the work of e.g. Gillespie, "Poets, Printers and Early English Sammelbände,” Huntington Library Quarterly 67 (2004), 189-214.

${ }^{28}$ Paul Needham, The Printer and the Pardoner (Washington, 1986), p. 65.

${ }^{29}$ Gillespie, “Poets, Printers,” pp. 200-01.

${ }^{30}$ Cayley, "Cyclification and Circulation”.

${ }^{31}$ Needham, Printer and Pardoner, p. 17. Unequivocal evidence of an early Sammelband is hard to establish; most have been split into individual bindings at the behest of antiquarian collectors. Gillespie provides a useful “checklist” of possible attributes (including early marginal notes, uniform decoration or provenance indications, etc; see Gillespie, “Poets, Printers,” pp. 195-9).

${ }^{32}$ See David Shaw, “Unrecorded French Incunables in the Thüringer Universitäts- und Landesbibliothek, Jena,” The Library, Sixth Series 19 (1997), 197-220.

${ }^{33}$ Ibid., 203; 208-20.

${ }^{34}$ The only Chartier text apparently considered long enough to circulate individually in a manuscript was the Livre des quatre dames; see Hult, “Authorial or Scribal,” p. 772. The LQD was not, however, printed as a single work. 
${ }^{35}$ Hult, “Authorial or Scribal,” p. 775.

${ }^{36}$ For Mansion’s texts and milieu, see LudoVandamme, “Colard Mansion et le monde du livre à Bruges," in Le Berceau du livre imprimé: autour des incunables, ed. Pierre Aquilon and Thierry Claerr (Turnhout, 2010), pp. 177-86. See also Joseph Van Praet, Notice sur Colard Mansion, libraire et imprimeur de la ville de Bruges (Paris, 1829). For more information on Caxton and his printing of Chartier works, see Kinch in this volume.

${ }^{37}$ See Le cinquième Centenaire de l'imprimerie dans les anciens Pays-Bas: catalogue (Brussels, 1973), pp. 227-38.

${ }^{38}$ See Mansion’s added prologue to the QI. Transcription from BnF, Rés..LB 2677.

${ }^{39}$ See 1477: Le privilège général et les priviléges régionaux de Marie de Bourgogne pour les

Pays-Bas, ed. W. P. Blockmans (Kortrik-Henle, 1985), esp. pp. 1-77 and pp. 97-125; and W. P.

Blockmans, “The Formation of a Political Union,” in A History of the Low Countries, ed. J. C. H.

Blom and C. Lamberts (New York, 1999), pp. 59-140.

${ }^{40}$ Catherine Nall, “Le Quadrilogue invectif and its English Readers,” in Chartier in Europe, pp. $135-47$.

${ }^{41}$ See Cinquième centenaire, no. 103 for prologue and Van Praet, Notice, 33-4 for epilogue.

${ }^{42}$ Cayley, “Poetry, Politics,” pp. 79-83.

${ }^{43}$ See Douglas Kelly, “Boethius as Model for Rewriting Sources in Alain Chartier's Livre de l'Espérance," in Chartier in Europe, pp. 1-30.

${ }^{44}$ Cayley, Debate and Dialogue, Appendix B, see also Hult, “Authorial or Scribal,” p. 772.

${ }^{45}$ [are translations of Italian humanists ... which stage characters from antiquity]. Anne Schoysman, “Recueil d'auteur, recueil thématique? Le cas de la diffusion manuscrite de textes 
sur le thème de la 'vraie noblesse' traduits par Jean Miélot,” in Le Recueil à la fin du moyen âge, pp. 277-87, at p. 278.

${ }^{46}$ On Miélot’s sources, see Schoysman, “Recueil d'auteur,” pp. 277-8, and on the presentation manuscript, p. 280.

${ }^{47}$ See Scot McKendrick and Thomas Kren, Illuminating the Renaissance (Los Angeles, 2005), pp. 59-78 on Burgundian book production.

${ }^{48}$ Cayley, Debate and Dialogue, esp. ch. 1 and 2; Armstrong, The Virtuoso Circle, ch. 1 and “The Deferred Verdict: A Topos in Late Medieval Poetic Debate?,” French Studies Bulletin 64 (1997), 12-14.

${ }^{49}$ Alain Chartier, Le Quadrilogue invectif, ed. Florence Bouchet (Paris, 2011), p. 83.

${ }^{50}$ Cf. Armstrong, Virtuoso Circle, ch. 1.

${ }^{51}$ Schoysman,“Recueil d'auteur,” pp. 280-81; p. 287.

${ }^{52}$ Quadrilogue, p. 8. On the QI's potential theatricality, see Le Quadrilogue invectif, trans.

Florence Bouchet (Paris, 2002), pp. 27-8.

${ }^{53}$ Cayley, Debate and Dialogue, p. 99. See also Claude Dalbanne and Eugène Droz, L'Imprimerie à Vienne-en-Dauphiné au quinzième siècle (Paris, 1930), p. 226.

${ }^{54}$ Cayley, Debate and Dialogue, p. 100: BnF, fr. 25293.

${ }^{55}$ Ibid, Appendix B.

${ }^{56}$ Cited from the final quatrain of Mansion's edition.

${ }^{57}$ See Van Praet, Notice, pp. 52-5.

${ }^{58}$ Also known as Johannes Solidi.

${ }^{59}$ Dalbanne/Droz, L'Imprimerie, p. 118; his Dyalogue (as he entitles the QI) contains mistakes which impede comprehension. 
${ }^{60}$ On the BDQEM's assumption into the Querelle de la Belle Dame sans mercy, see A. Piaget, “La Belle Dame sans mercy et ses imitations,” Romania 33 (1904), 200-08 and Joan McRae, The Quarrel of the Belle Dame Sans Mercy (New York, 2004), pp. 20-21 and 26-27.

${ }^{61}$ See Cayley, “Poetry, Politics,” pp. 77-8 and Debate and Dialogue concerning the ethical cohesiveness of Chartier's literary output.

${ }^{62}$ Van Praet, Notice, p. 50.

${ }^{63}$ [seem to have been printed in view of uniting them in a single volume] Catalogue des Livres de la bibliothèque de Feu M. le Comte de MacCarthy Reagh (Paris, 1815), I, no. 2843.

${ }^{64}$ Van Praet, Notice, p. 37.

${ }^{65}$ Cayley, “Poetry, Politics,” p. 76. Cayley reads the QI's debate between France and the three estates in the pro-feminine context of the BDSM and the LQD. See Debate and Dialogue, pp. $113-4 ; 117 ; 125$.

${ }^{66}$ Jennifer Goodman, “Caxton’s Continent,” in Caxton's Trace: Studies in the History of English Printing, ed. William Kuskin (Notre Dame, 2006), pp. 101-23, at p. 108.

${ }^{67}$ Goodman, “Caxton’s Continent,” pp. 106-7. ${ }^{68}$ These are Van Praet's own (Notice, 25-6), and a 1779 description documenting the arrival of the volume in Heiss’s collection: L’Abbé de St Léger, “Observations sur la lettre de M. J. G. [...] avec une notice de quelque Editions faites à Bruges par Colard Mansion [...],” L’Esprit des Journaux (nov. 1779), 236-49.

${ }^{69}$ L’Abbé de St Léger, “Observations,” p. 244.

70“'A thick, folio volume printed in black-letter type, it appeared that this volume contained eight editions printed in Bruges by Colard Mansion”, Ibid.,pp. 245-9. 
${ }^{71}$ Notice, 26. The OB Brugge holds almost all its Mansion editions as a result of gifts or legacy from Van Praet; see Pierre-Joseph Laude, Catalogue méthodique de la Bibliothèque publique de Bruges (Bruges, 1847), 654-69.

${ }^{72}$ The BnF holds two copies of the Adevineaux, printed by Mansion; these comprise two different versions of the text, however; cf. Van Praet, Notice, pp. 47-9.

${ }^{73}$ L’Abbé de St Léger, “Observations,” p. 248.

${ }^{74}$ Rés. D.862 is a puzzle; it has hitherto been described as containing a completely different set of Colard Mansion copies to those which formed the recueil Heiss. However, the distinctive provenance note found in Rés.. D.862's Débat clearly identifies it as that referred to in the 1779 description of the recueil Heiss. See further Olivia Robinson, “A Note on the Provenance of BnF Rés D.862, A Collection of Colard Mansion Prints”, Journal of the Early Book Society 16 (2013), 249-59.

${ }^{75}$ This copy of the Doctrinal does not contain the "Thomas" signature; however, it does share the feature of a red handwritten title on its opening folio with the "Thomas"-owned copies of the QI and the Adevineaux.

${ }^{76}$ See Guillaume Fau, Sarah Sakok, Marie Smouts and Sylvie Tisserand, “L’imprimerie à Lyon au XVè siècle: un état des lieux,"Revue française d'histoire du livre 118-21 (2005), 191-277, 193.

${ }^{77}$ On printing in Lyon at this time, see: Fau et al, “Etat des lieux,” Dominique Coq, “Les incunables: textes anciens, textes nouveaux," Histoire de l'édition française I (Paris, 1982), 18084 and Anatole Claudin, Histoire de l'imprimerie en France au XVè et au XVIè siècle, III-IV (Paris, 1915).

${ }^{78}$ See Hillard, “Histoires d'L,” p. 87 on differences between Lyonnais and Parisian markets. 
${ }^{79}$ See Hillard, "Histoires d'L" on attempts to identify this figure, most recently as the printer Jean du Pré de Lyon. Hillard's evidence suggests, however, that du Pré probably was not the ICD. See pp. 86-7.

${ }^{80}$ The Hôpital is collected with Chartier works in 22 extant manuscripts. See McRae, The Quarrel, p. 26. On its role in the Querelle, see Hult/McRae, Le Cycle, "Introduction,” McRae, "The Trials," and Armstrong, Virtuoso Circle, ch.1. Ten of a possible 19 manuscripts provide the $B D Q E M$ with a title or rubric associating it with Chartier or the BDSM, as do printed Fais volumes, see McRae, The Quarrel, pp. 26-27.

${ }^{81}$ See Cayley “Debating Communities,” pp. 193-4.

${ }^{82}$ See Hult/McRae, Le Cycle, p. 1.

${ }^{83}$ On the structural mechanics of the Demandes et réponses and relevance to Chartier's amatory debate poetry, see Cayley, Debate and Dialoge, pp. 12-13.

${ }^{84}$ See Swift, Gender, Writing, ch. 2, esp. pp. 151-2.

${ }^{85}$ See Hult/McRae, Cycle, lxv-vi and Laidlaw, Poetical Works.

${ }^{86}$ McRae, “Cyclification and Circulation,” cited at p. 104.

${ }^{87}$ Cayley, Debate and Dialogue, ch. 4; McRae, “The Trials” and "Cyclification and Circulation”. Ad hoc "booklet" construction does not preclude retrospective matching rubrication/decoration, see Ibid., p. 103.

${ }^{88}$ On this manuscript, sometimes called the "Diesbach manuscript," see Piaget, "La Belle dame et ses imitations,"Romania 4 (1905), 597-602 and McRae, “Cyclification and Circulation,” pp. 95-96, as well as her contribution to this volume. 
${ }^{89}$ It is usual to attribute a pre-Querelle author to the poem, often Oton de Grandson; however cf. McRae's comments, The Quarrel, pp. 20-21. It is certainly possible that the BDQEM was in fact a genuine (as opposed to adopted) contribution to the Querelle.

90“Entour sa [Chartier's] tombe, en lectres d'or / Estoit tout l'art de rhetorique” [around his tomb, in golden letters, was all the art of rhetoric], Hôpital, ll. 425-440. Cf. Hult, "Authorial or Scribal,” pp. 777-8 on a similar reason for the Hôpital's inclusion in collected Chartier prints. ${ }^{91}$ McRae, The Quarrel, p. 16.

${ }^{92}$ Hillard, “Histoires d’L,” p. 86.

${ }^{93}$ See CIBN C-270.

${ }^{94}$ See Catalogue des livres du cabinet de M. de Cangé (Paris, 1733), p. 83.

${ }^{95}$ The final text in this volume was printed $1489-1515$ in Paris; the binding must, therefore, have dated to after this time.

${ }^{96}$ Both are stylistically distinctive; Ortuin imported his 1489 Pelerinage cuts from the first German edition (Mainz, 1486), see Claudin, Histoire, III, pp. 397-408.

${ }^{97}$ See Dalbanne/Droz, Imprimerie, fig. 145.

${ }^{98}$ Ibid., pp. 255-31.

${ }^{99}$ Jena, ULB A. I. XII. q. r. Inc. See Dalbanne/Droz, Imprimerie, pp. 253-4, 273-5 and figs 170-3 on Schenck’s Vienne and Lyon Patiences.

${ }^{100}$ Shaw, “Unrecorded Incunables,” p. 198.

${ }^{101}$ See Claudin, Histoire, III, pp. 305-6.

${ }^{102}$ On which see Cayley, Debate and Dialogue, pp. 136-8, 156-62.

${ }^{103}$ See Xavier Ferrieu, 500 Ans de l'Imprimerie en Bretagne (Rennes, 1985), pp. 21-22. 
${ }^{104}$ See Ibid. ,p. 21 and Arthur La Borderie, L'Imprimerie en Bretagne au Xve siècle (Nantes, 1878).

${ }^{105}$ It contains, in order, Lois des trespassés avec le pelerinage maistre Jehan de Meung; Oraison de Pierre de Nesson; Trespassement nostre dame; Songe; BN and La Patience de Griseldis. La Prise de Grenade (possibly Troyes, Guillaume le Rouge, post-1492) is also now bound at the end of Rés. Ye 1154.

${ }^{106}$ See CIBN A-558. The Secret is the seventh short text (6 folios).

${ }^{107}$ La Borderie, L'Imprimerie, pp. 6-7.

${ }^{108}$ However, cf. Cayley, “Debating Communities,” p. 196, which reads them as a critique of empty linguistic commonplaces.

${ }^{109}$ See E. Golenistcheff-Koutouzoff, L'Histoire de Griseldis en France au XIVe et XVe siècle (Paris, 1933), pp. 34-8.

${ }^{110}$ La Borderie, L’'Imprimerie, p. 5, my emphasis.

${ }^{111}$ BnF, fr. 1161, Arsenal 3253, Vat. Reg. Lat. 1323 and Sion, Supersaxo 97 bis.

${ }^{112}$ Cayley, “Debating Communities,” pp. 193-4.

${ }^{113}$ The ICD and Fouquet-Crès Songes preserve different versions of the text; a third, now-lost edition existed, probably the same version as Foucquet-Crès, but with woodcuts. See A. de Montaiglon, Recueil de poésies françoises des xve et xvie siècles, III (Paris, 1856), p. 204. ${ }^{114}$ Cayley notes the relevance of Griselda's story to Chartier's “defence of women and of moral values”. See “Debating Communities,” p. 199.

${ }^{115}$ See Golenistcheff-Koutouzoff, Griseldis, chs 2 and 3. On the Livre, see Swift, Gender, Writing, pp. 148-50.

${ }^{116}$ See Cayley, “Debating Communities,” p. 199. 
${ }^{117}$ Golenistcheff-Koutouzoff, Griseldis, pp. 40-41.

${ }^{118}$ Cayley, Debate and Dialogue, p. 10. 